\title{
POLARIZAÇÃO POLÍTICA NA ERA DIGITAL: VIOLÊNCIA, DESINFORMAÇÃO E DEBATE
}

\section{MAÍLA MOREIRA DIAS}

Graduanda em Direito modalidade Integral - Escola Superior Dom Helder Câmara. Belo Horizonte-MG. E-mail: mailamoreira.dias@gmail.com

\section{THALES EUGÊNIO ARAÚJO ROCHA}

Graduando em Direito modalidade Integral - Escola Superior Dom Helder Câmara. Belo Horizonte-MG. E-mail: thaleseugenio58@gmail.com

\section{CAIO AUGUSTO SOUZA LARA}

Mestre e Doutor em Direito pela Faculdade de Direito da Universidade Federal de Minas Gerais - UFMG. Professor da Escola Superior Dom Helder Câmara. Pesquisador associado ao Programa RECAJ-UFMG - Acesso à Justiça e Solução de Conflitos. Secretário de Comunicação do Conselho Nacional de Pesquisa e Pósgraduação em Direito - CONPEDI. Belo Horizonte-MG. E-mail: caiolarabh@yahoo.com.br.

\section{RESUMO}

O tema-problema da pesquisa que se pretende desenvolver é o aumento da violência no que tange a intolerância com a pluralidade de ideias e posicionamentos político-sociais em ambiente virtual, bem como as violações de direitos correspondentes. Analisa-se as raízes históricas e sociológicas responsáveis por disseminar tamanha intolerância presentes, em maior peso, em períodos eleitorais e percebe-se como a diferença de opiniões parte do viés negativo, ao invés de preservar uma atividade dialética produtiva. Ao averiguar a evolução histórica da sociedade 


\section{Personalidade Acadêmica Homenageada:}

Raymundo Juliano Feitosa (Universidade Federal do Rio Grande do Norte - UFRN)

brasileira, constata-se que a hostilidade é um elemento marcante. É comum apontar que demais países da América do Sul são demasiados violentos e marcados por diversas guerras civis, mas há de se esquecer que a memória do Brasil consta diversos conflitos. Cabanagem, Farroupilha, Balaiada são algumas das várias revoltadas ocorridas e que tiveram como uma das principais características tal ferocidade. Outros episódios que constatam a presença deste fato em nossa cultura é a morte de Zumbi dos Palmares e de Tiradentes, ambos foram esquartejados e tiveram suas cabeças expostas ao público. Em vista desta informação, é impossível não observar o histórico violento do Brasil, o que fundamenta a violência em razão de ideologia política, tendo como base o fato de que o brasileiro nutre o sentimento imposto em tempos passados. O modo, pré-definido, para resolver os conflitos e, então, a disparidade de ideias, é o uso de uma postura autoritária, que pode demandar violência. Ressalta-se que o avanço tecnológico propiciou o desenvolvimento de celulares e tecnologias avançadas que incentivaram a comunicação e disseminação de informações. O problema objeto da investigação científica proposta é: quais são as implicações históricas e sociológicas do fenômeno da polarização política no Brasil e em quais âmbitos? Quais os direitos afetados por estas violações? A partir das reflexões preliminares sobre o tema, é possível afirmar inicialmente que o ódio compromete o exercício da democracia e da cidadania, principalmente em época de eleição, haja visto que esse é o período em que o debate político toma conta das massas populares e, automaticamente, propicia o confronto de ideias. Este fato é ainda mais alarmante tendo como parâmetro o século XIX, posto que o avanço da internet e a maior facilidade de acesso auxilia o aumento na taxa de disseminação da intolerância. $O$ objetivo geral do trabalho é analisar a realidade da violência, cada vez mais alarmante, no que diz respeito a ideologia política e também verificar a explicação da ocorrência crescente do ato incomplacente. Examinam-se, ainda, as sequelas impostas na sociedade contemporânea e os seus desdobramentos jurídicos, como por exemplo, com a ocorrência de crimes contra a honra e violação da intimidade. A pesquisa que se propõe pertence à vertente metodológica jurídicosociológica. No tocante ao tipo de investigação, foi escolhido, na classificação de Witker (1985) e Gustin (2010), o jurídico-projetivo. O raciocínio desenvolvido na 
Personalidade Acadêmica Homenageada:

Raymundo Juliano Feitosa (Universidade Federal do Rio Grande do Norte - UFRN)

pesquisa é predominantemente dialético. De acordo com a técnica de análise de conteúdo, afirma-se que se trata de uma pesquisa teórica (ou pesquisa de campo, para quem for precisar de questionários para responder às perguntas formuladas), o que será possível a partir da análise de conteúdo dos textos doutrinários, normas e demais dados colhidos na pesquisa. A partir do exposto, conclui-se que o discurso de ódio político em ambiente virtual tem lastro nas raízes históricas brasileiras. Em anos eleitorais, como 2018, o fenômeno em estudo tende a aparecer com mais força, agora catalisado pelas ferramentas disponíveis nas redes sociais. Conclui-se pela necessidade de propor novos instrumentos jurídicos e sociais de combate à disseminação massiva de conteúdos odiosos em ambiente virtual.

PALAVRAS-CHAVE: Era Digital; Disseminação; Crimes contra a honra; Violação da intimidade.

\section{REFERÊNCIAS}

CAULYT, Fernando. "Sociedade brasileira cultua a violência", diz sociólogo. Portal Uol. 2017. Disponível em: https://noticias.uol.com.br/ultimasnoticias/deutschewelle/2017/10/09/sociedade-brasileira-cultua-a-violencia.htm. Acesso em 9 mai. 2019.

FARRANHA, Ana Claudia; SANTOS, Viviane Silva; REIS, João Carlos; SANTOS, Leonardo Tadeu. DEMOCRACIA, PARTICIPACCÃO E REDES SOCIAIS DIGITAIS: DESAFIOS CONTEMPORÂNEOS DA POLITTICA E DO DIREITO. Revista Unicuritiba. $\quad V . \quad 3, \quad$ n. 44 (2016). Disponível em: http://revista.unicuritiba.edu.br/index.php/RevJur/article/view/1740. Acesso em: 20 mai. 2019.

GONÇAVES, Alicianne. Violência no período eleitoral aumenta e chama atenção da ONU. 2018. Disponível em: https://ufmg.br/comunicacao/noticias/violencia-noperiodo-eleitoral-aumenta-e-chama-atencao-da-onu. Acesso em 10 mai. 2019.

GUSTIN, Miracy Barbosa de Sousa; DIAS, Maria Tereza Fonseca. (Re)pensando a pesquisa jurídica: teoria e prática. 3ª . ed. Belo Horizonte: Del Rey, 2010. 
Personalidade Acadêmica Homenageada:

Raymundo Juliano Feitosa (Universidade Federal do Rio Grande do Norte - UFRN)

KARNAL, Leandro. Todos contra todos: o ódio nosso de cada dia. Lisboa: Leya, 2017.

ONU condena atos de violência durante período eleitoral no Brasil. Portal G1. 12 de Out 2018.2 Disponível em: https://g1.globo.com/google/amp/politica/eleicoes/2018/noticia/2018/10/12/onucondena-atos-de-violencia-durante-periodo-eleitoral-no-brasil.ghtml. Acesso em: 10 mai. 2019.

ONU manifesta preocupação com atos de violência durante período eleitoral no Brasil. Portal O Globo. 13 out 2018. Disponível em: https://oglobo.globo.com/brasil/onumanifesta-preocupacao-com-atos-de-violencia-durante-periodo-eleitoral-no-brasil23153430?versao=amp. Acesso em 10 mai. 2019.

WITKER, Jorge. Como elaborar uma tesis en derecho: pautas metodológicas y técnicas para el estudiante o investigador del derecho. Madrid: Civitas, 1985. 